"Reliability of corporate environmental reports produced by listed South African companies"

AUTHORS

ARTICLE INFO

DOI

RELEASED ON

JOURNAL

FOUNDER

\section{Peter Nasiema Kamala}

Peter Nasiema Kamala (2016). Reliability of corporate environmental reports produced by listed South African companies. Environmental Economics, 7(2), 2939. doi:10.21511/ee.07(2).2016.3

http://dx.doi.org/10.21511/ee.07(2).2016.3

Friday, 03 June 2016

"Environmental Economics"

LLC "Consulting Publishing Company "Business Perspectives"

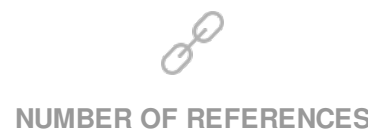

0
NUMBER OF FIGURES

0

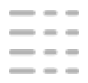

NUMBER OF TABLES

0

(C) The author(s) 2022. This publication is an open access article. 
Peter Nasiema Kamala (South Africa)

\title{
Reliability of corporate environmental reports produced by listed South African companies
}

\begin{abstract}
The aim of this research is to evaluate the reliability of environmental reports produced by the Top 100 listed South African (T100LSA) companies. A content analysis of environmental reports contained in the Integrated Annual Reports (IARs), sustainability reports and companies' corporate websites was conducted using a control list.
\end{abstract}

The findings of the study reveal that in general, the environmental reports produced by the T100LSA companies are reliable as most companies' reports have a statement from the top management, describe the organization's structures in place at various levels to deal with environmental matters, as well as the initiatives undertaken to mitigate environmental impacts. In addition, most companies disclose their external recognition for environmental achievement or their involvement with external parties on environmental matters. Furthermore, most of the companies' reports contain third party commentary and indicate that the companies have adopted the best practice in environmental performance management and reporting.

Besides, most companies report in a balanced manner including both positive and negative information pertaining to risks faced and the opportunities missed or seized, as well as their environmental policy, mission, objectives and strategies. However, there was a need for improvement, as only a half of the companies' environmental reports had an assurance statement from an independent party, which mostly failed to indicate the procedures performed by the assuror.

Keywords: reliability, environmental reports, content analysis.

JEL Classification: Q56.

\section{Introduction}

The recent corporate scandals and environmental transgressions by high profile companies, such as unabated oil spills, have heightened the public sensitivity on environmental issues (Alrazi, De Villiers \& VanStaden, 2011, p. 3; Bond, 2013, p. 694). The latter has led to growing distrust of the environmental information reported companies (IRC, 2011, p. 01).

In response, companies have simply increased the number and volume of their environmental reports produced (Marquis \& Toffel, 2014, p. 04). However, the increase has done little to assuage the distrust of the members of the public for various reasons (IRC, 2011, p. 01). Firstly, overwhelming criticism has suggested that the environmental reports produced tend to be biased and/or selflaudatory with minimal negative information disclosure even when such information is known to exist (Delmas \& Burbano, 2011, p. 64). Secondly, companies with the most obvious impact on the environment tend to report more comprehensively than those with lesser impact, in an attempt to legitimize their activities (KPMG, 2013, p. 07).

Thirdly, only a low percentage of companies have undertaken reasonable assurance of their environmental reports partly due to a lack of wellestablished verifying methods (Strandberg Consulting,

(C) Peter Nasiema Kamala, 2016.

Peter Nasiema Kamala, Dr., Department of Management Accounting, Cape Peninsula University of Technology, South Africa.
2013, p. 05). The latter has resulted in assurance statements that vary significantly with regard to their title, range of objectives, scope of assignment, description of the nature, timing and extent of procedures employed, as well as the wording of conclusions offered (Furmann, Ott, Looks \& Gunther, 2013, p. 02). Furthermore, most assurance statements do not include any recommendations for improvement either from accuracy or internal control systems point of view, therefore, they offer little insight into how the assurance process is useful to a company's environmental reports (Furmann et al., 2013, p. 02). Besides, assurance engagements are determined by and undertaken for the companies' management, a tendency which has undermined the perceived independence of the assurance providers (ACCA, 2009, p. 08).

Fourthly, where companies have opted for thirdparty commentary to boost the credibility of their environmental reports, such commentary has tended to biased, typically portraying a company's report in a favorable manner, and lacking resentful voices (BSMC, 2010, p. 21). Given the above mentioned shortcomings, debate is rife as to whether the environmental information produced by companies is reliable (Said, Ahmad \& Senik, 2013, p. 440).

In the South African context, the question of whether environmental reports produced by companies are reliable, was last examined more than five years ago (De Villiers \& Van Staden, 2010). This research aims to fill this gap in the literature by evaluating the content of the environmental reports 
produced by the T100LSA companies. Accordingly, the main objective of this study is to evaluate the reliability of corporate environmental reports produced by T100LSA companies.

The rest of the article proceeds as follows: Section 1 reviews the relevant prior literature. Section 2 provides the methodology, followed by results and discussion in Section 3. Section 4 provides the summary and conclusion of the article.

\section{Literature review}

Reliability is a qualitative characteristic of accounting information that is achieved when the information is complete, neutral, free from error and verifiable (FASB, 2010, p. 17). Reliability of environmental reports has been questioned for various reasons. To start with, despite the efforts of many companies to include assurance statements in their reports, the assurance statements have tended to vary significantly with regard to their title, range of objectives, scope of assignment, description of the nature, timing and extent of procedures employed, as well as the wording of conclusions offered. These have undermined the credibility of the reports to readers (Fonseca, 2010, p. 19; Strandberg, 2013, p. 12).

In addition, most of the assurance statements in environmental reports do not include, or refer to, any recommendations for improvement, either from a content accuracy or internal systems point of view, therefore, they offered little insight into how the assurance process was useful to a company's reporting and performance (BSMC, 2010, p. 28). Furthermore, only a few companies undertake an independent reasonable assurance given that it requires a detailed examination of evidence used to support the assertions made in the reports (ACCA, 2009, p. 05; Ernst \& Young, 2007, p. 23). Instead, most companies opt for less costly, limited form of assurance that does not require a detailed examination of evidence (ACCA, 2009, p. 09).

As a result of the above mentioned weaknesses in the assurance process, most environmental reports tend to be declarative and biased on positive information even when negative information is known to exist (Sustainability, FBDS \& UNEP, 2008, p. 14). In addition, most of the performance measurement systems adopted are inept and error prone, given their manual nature (Ernst, Young, \& Greenbiz, 2013, p. 30). In addition, the environmental information reported is hardly rigorously quantified, and is often presented in a vague manner that undermines its accuracy (Sustainability et al., 2008, p. 19). Worse still, some companies provide cautionary statements about the nature of the information contained in those reports (Kolk, 2005, p. 40). As a result, many stakeholders perceive the environmental reports as unreliable (IRC, 2011, p. 01).

Some researchers have lamented the apparent disconnect between the environmental reporting practice and the actual environmental performance of most companies (Leavoy, 2010, p. 01). In fact, companies experiencing an environmental crisis have been reported to disclose vague information (green-wash) to create the impression of being environmentally sensitive (Delmas \& Burbano, 2011, p. 64). Worse still, somecompanies have won environmental reporting awards and rankings despite having a dismal environmental performance record (Cohen, 2014, p. 01). Other researchers have opined that users were asking for more reliable environmental information than they were receiving (Haque, Deegan \& Inglis, 2013, p. 21).

Consistent with the international trends, studies conducted on environmental reporting in South Africa have revealed that users want more reliable environmental information than was being provided (De Villiers \& Van Staden, 2010, p. 442; Mitchell \& Quin's, 2005, p. 26). The studies have further found that environmental reports provided were perceived to be insufficient, unsystematic and unreliable. Unlike in the developed countries, there is a paucity of research which investigates the decisionusefulness, and, particularly, the reliability of environmental reports in South Africa as most of the research in the country is outdated, therefore, there is a need for more recent research. This study aims to fill in the gap in the literature by investigating the reliability of environmental reports produced by the T100LSA companies.

\section{Methodology}

Content analysis methodology was employed to evaluate the reliability of corporate environmental reports produced by the T100LSA companies. This methodology was systematically used to identify presence of specified characteristics of messages related to reliability of the environmental reports located in IARs, websites and corporate sustainability reports, regardless of whether the messages were in form of text, audio, video, graphical or pictorial. This method was preferred, because it is an unobtrusive technique that avoids problems of non-response bias, and that enables a researcher to collect data in a variety of forms (Zadjali, 2011, p. 01).

\subsection{Design of the research instrument.} Environmental reports are reliable when they contain a statement from the most senior decision maker of a company, disclose the organization's structure, divulge the initiatives undertaken to 
mitigate the environmental impacts, demonstrate external recognition and involvement, are independently attested to and if they contain independent third party commentary (Delloite Touche Tohmatsu, 2002, p. 40; GRI, 2006, p. 17). In addition, environmental reports are reliable when the content is reported in a balanced manner, risk and opportunities are divulged candidly, and if policies, objectives and strategies are disclosed (Delloite Touche Tohmatsu, 2002, p. 13; GRI, 2006, p. 03). Accordingly, the disclosure of the above mentioned items can and was used as a proxy to gauge the reliability of the reports. To this end, a checklist was designed from the Global Reporting Intitiaves' guidelines which are the de facto standards for environmental reporting (Fonseca, 2010, p. 05). The checklist contained key items identified above, disclosure of which would indicate the reliability of an environmental report.

2.2. Data collection. The data collection exercise entailed scanning of IARs, corporate sustainability reports and websites of companies to determine the presence of pre-listed items, related to reliability of environmental reports, which were contained in a control list. The total number of companies whose environmental reports contained a pre-listed item was computed and expressed as a percentage of the total number of sampled companies. These were, then summarized in Tables under a column titled "Companies that disclose". Likewise, the total number of companies whose environmental reports did not contain a pre-listed item was computed and expressed as a percentage of the total number of sampled companies. These were, then, summarized in Tables under a column titled "Companies that do not disclose" (see tables 1, 2, 3, 4, and 5).

2.3. Population and sample selection. The population of the proposed research comprised the top 100 operating companies on the Johannesburg Securities Exchange (JSE). The sample consisted of 66 top 100 JSE listed operating companies based on market capitalization, as quoted on the Sharenet website - a reliable website that provides on-line information on companies listed on the JSE - on 1st January 2015. The 44 companies excluded from the sample were either investment companies which do not undertake operational activities or subsidiaries of holding companies already included in the sample, or simply listed securities, given that they are not physical companies.

The top 100 JSE listed operating companies were selected because of their significant environmental impact in the areas in which they operate, given their large sizes and presence in many provinces of South Africa. In addition, their IARs, sustainability reports and company websites were more readily available than those of other forms of businesses.

\section{Results and discussions}

3.1. Disclosure of a statement from top management and the organizational structure that deals with environmental matters. Disclosure, in the environmental report, of a statement from the top management of a company outlining the vision, mission, strategic environmental plans and objectives of a company sets the tone of the report and establishes credibility with the users (GRI, 2000, p. 23). Coming from the top, such a statement enhances the reliability of the environmental report, as opposed to a statement from a junior employee, as the top management has a broad view of the organization and is in a position to influence decisions.

According to GRI (2000, p. 23), to establish credibility of the environmental report, a statement from the top management contained therein must candidly highlight the successes, failures, current and future challenges, top management involvement in management of environmental issues, refer to key elements of the report, declare commitment to address environmental issues, invite stakeholder's feedback and include broader trends in environmental performance. The disclosure of these key elements demonstrates transparency and accountability, thus, can be used to gauge the reliability of an environmental report.

Similarly, the extent of disclosure of a company's organizational structure including the various management levels that deal with environmental issues, board oversight of environmental issues, principal functions of committees, departments and personnel charged with management of environmental issues demonstrates a company's commitment to environmental issues, and, thus, can be used to gauge the reliability of the environmental report.

As shown in Table 1, the results of the current study show that $97 \%$ of the sampled companies' environmental reports disclosed a statement from the top management that discussed environmental matters. The results also indicate that $65 \%$ of the companies' statements discussed candidly their environmental successes, failures, current and future challenges in the statements from the top management. Similarly, 67\% of the sampled companies' statements addressed their current and future environmental challenges in their statements. Likewise, $70 \%$ of the companies disclosed the top management's involvement in implementation of the company's environmental principles, values, policies, and strategies. Correspondingly, $70 \%$ of the companies' statements referred to key elements of the report, thus, setting the tone for the rest of the report. 
Table 1. Disclosure of a statement from top management and the organizational structure that deals with environmental matters

\begin{tabular}{|c|c|c|c|c|c|}
\hline No & Category & Disclosure item & $\begin{array}{c}\text { Percentage of } \\
\text { companies that } \\
\text { disclose }\end{array}$ & $\begin{array}{l}\text { Percentage of } \\
\text { companies that do not } \\
\text { disclose }\end{array}$ & Total \\
\hline 1 & $\begin{array}{l}\text { Statement from the } \\
\text { top management }\end{array}$ & Statement from the top management & $97 \%$ & $3 \%$ & $100 \%$ \\
\hline 1.1 & & $\begin{array}{l}\text { Statement candidly discloses current environmental } \\
\text { successes, failures, current and future challenges }\end{array}$ & $65 \%$ & $35 \%$ & $100 \%$ \\
\hline 1.2 & & $\begin{array}{l}\text { Statement includes a commitment by top management to } \\
\text { address current and future environmental challenges }\end{array}$ & $67 \%$ & $33 \%$ & $100 \%$ \\
\hline 1.3 & & $\begin{array}{l}\text { Statement describes top management's involvement in } \\
\text { implementation of the company's environmental principles, } \\
\text { values, policies, and strategies }\end{array}$ & $70 \%$ & $30 \%$ & $100 \%$ \\
\hline 1.4 & & $\begin{array}{l}\text { Statement refers to key elements of the report, thus, sets } \\
\text { the tone for the rest of the report }\end{array}$ & $70 \%$ & $30 \%$ & $100 \%$ \\
\hline 1.5 & & $\begin{array}{l}\text { Statement contains a declaration of top management's } \\
\text { commitment to address key concerns raised by } \\
\text { stakeholders and invites them to provide feedback on the } \\
\text { report }\end{array}$ & $47 \%$ & $53 \%$ & $100 \%$ \\
\hline 1.6 & & $\begin{array}{l}\text { Statement includes broader trends in environmental } \\
\text { performance, and progress on targets }\end{array}$ & $50 \%$ & $50 \%$ & $100 \%$ \\
\hline 2 & $\begin{array}{l}\text { Organizational } \\
\text { structure that deals } \\
\text { with environmental } \\
\text { matters }\end{array}$ & $\begin{array}{l}\text { Description of the organization's structures in place at } \\
\text { various levels to deal with environmental matters }\end{array}$ & $99 \%$ & $1 \%$ & $100 \%$ \\
\hline 2.1 & & $\begin{array}{l}\text { Indication that oversight of environmental issues is done at } \\
\text { the board level }\end{array}$ & $99 \%$ & $1 \%$ & $100 \%$ \\
\hline 2.2 & & $\begin{array}{l}\text { Mention of membership, principal functions, roles and } \\
\text { responsibilities of environmental steering committees, } \\
\text { teams, personnel or departments }\end{array}$ & $97 \%$ & $3 \%$ & $100 \%$ \\
\hline 2.3 & & $\begin{array}{l}\text { Mention the person who/or committee that bears ultimate } \\
\text { responsibility for environmental issues }\end{array}$ & $99 \%$ & $1 \%$ & $100 \%$ \\
\hline
\end{tabular}

Only $47 \%$ of the sampled companies' statements from top management contained a declaration of their commitment to address key concerns raised by stakeholders or invited the stakeholders to provide feedback on the report. Similarly, only $50 \%$ of the sampled companies' statements included broader trends in environmental performance, and progress on targets.

Results further show that $65 \%$ of the sampled companies had an organizational structure that deals with environmental matters. An equal percentage disclosed that the oversight of environmental issues was done at the board level. Likewise, $64 \%$ of the sampled companies mentioned the membership, principal functions, roles and responsibilities of environmental steering committees, teams, personnel or departments, while $65 \%$ mentioned the person/ committee that bore the ultimate responsibility for environmental issues.

3.2. Disclosure of the initiatives undertaken to mitigate environmental impacts, external recognition and involvements. Disclosure of the initiatives undertaken to mitigate environmental impacts illustrates a company's commitment to follow through with its plans with concrete action which enhances stakeholders' trust in the company and that of its environmental reports. On the other hand, external recognition in form of reporting awards and high ranking in reporting ranking schemes does not only indicate the adoption of the best practice, but it also signifies trust and acceptance of a company's report by external parties and its peers who are more likely to be objective in their assessment. This does not only enhance the reliability of the report, it also shows that the report can withstand external scrutiny. Besides, when a company's report wins awards, or tops a ranking scheme, its image and credibility of its environmental reports improves in the eyes of the stakeholders (Emtairah, 2002, p. 30). This is because the judgment criteria of most of the awards and ranking scheme is centred on reliability of the reports as perceived by a panel of experts, mostly assurance providers (Hibbit, 2004, p. 44). Therefore, the disclosure of the initiatives undertaken to mitigate environmental impacts, external recognition and involvements can be used to gauge the reliability of the environmental report. 
Table 2. Disclosure of the initiatives undertaken to mitigate environmental impacts, external recognition and involvements

\begin{tabular}{|c|l|l|c|c|c|}
\hline No & \multicolumn{1}{|c|}{ Category } & \multicolumn{1}{|c|}{ Disclosure item } & $\begin{array}{c}\text { Percentage of } \\
\text { companies that } \\
\text { disclose }\end{array}$ & $\begin{array}{c}\text { Percentage of } \\
\text { companies that do } \\
\text { not disclose }\end{array}$ & \begin{tabular}{c} 
Total \\
\hline 3
\end{tabular} \\
\hline $\begin{array}{l}\text { Initiatives } \\
\text { undertaken to } \\
\text { mitigate } \\
\text { environmental } \\
\text { impacts }\end{array}$ & $\begin{array}{l}\text { General description of the initiatives undertaken to mitigate } \\
\text { environmental impacts }\end{array}$ & $100 \%$ & $100 \%$ \\
\hline 4 & $\begin{array}{l}\text { External recognition } \\
\text { and involvement }\end{array}$ & $\begin{array}{l}\text { External recognition for environmental achievement or their } \\
\text { involvement with external parties on environmental matters }\end{array}$ & $80 \%$ & $20 \%$ & $100 \%$ \\
\hline 4.1 & & Awards they received or ranking in a ranking scheme & $59 \%$ & $41 \%$ & $100 \%$ \\
\hline 4.2 & & $\begin{array}{l}\text { Involvement with external parties in initiatives aimed at } \\
\text { establishing environmental measurement procedures and } \\
\text { benchmarks }\end{array}$ & $65 \%$ & $35 \%$ & $100 \%$ \\
\hline 4.2 & & $\begin{array}{l}\text { Involvement with external parties in initiatives aimed at } \\
\text { establishing environmental measurement procedures and } \\
\text { benchmarks }\end{array}$ & $65 \%$ & $35 \%$ & $100 \%$ \\
\hline 4.3 & & $\begin{array}{l}\text { Membership in environmental associations, industry } \\
\text { associations, national and international associations }\end{array}$ & $76 \%$ & $24 \%$ & $100 \%$ \\
\hline
\end{tabular}

As indicated in Table 2, all the sampled companies provided a general description of the initiatives they undertook to mitigate the environmental impacts of their activities, products or services. With regard to external recognition for environmental achievement or their involvement with external parties on environmental matters, $80 \%$ of the sampled companies disclosed this item, while 59\% mentioned the awards they received or ranking in a ranking scheme. Of the sampled companies, 65\% disclosed their involvement with external parties in initiatives aimed at establishing environmental measurement procedures and benchmarks, while $76 \%$ disclosed their membership in environmental associations, industry associations, national and international associations.

3.3. Disclosure of an assurance statement in the environmental report. Arguably, the single most effective for enhancing reliability of an environmental report is by subjecting it to external assurance and including in it the resulting assurance statement. Not only does the inclusion of an assurance statement in a company's environmental report increase a company's stakeholders' recognition, trust and credibility in its reports, but it also provides them with confidence in the environmental disclosures and reflects a company's seriousness with regard to the items reported. In addition, an assurance statement attests to the data quality and accuracy of the information reported, reduces restatements in the reports. Furthermore, assured environmental disclosures are viewed as robust, credible and are more likely to be relied upon by stakeholders when making decisions. Besides, an assurance statement may confirm the presence or absence of robust internal control systems, and recommend any neccesary improvements. This enhances the reliability of the information from such a system. In short, the extent of the disclosure of an assurance statement can be used to gauge the reliability of an environmental report.

As shown in Table 3, 50\% of the sampled companies' environmental reports contained an assurance statement from an independent party. All the environmental reports with an assurance statement were assured using either ISAE 3000 or the AA1000. The results of the current study also show that all the environmental reports with an assurance statement indicated the type/level of assurance provided. However, this almost entirely comprised limited assurance, with a few reports indicating a reasonable assurance for a few selected items in addition to the general limited assurance. Furthermore, the results of the current study indicate that all environmental reports with an assurance statement described the assurance engagement and identified the subject matter of the assurance engagement.

Table 3. Disclosure of an assurance statement in the environmental report

\begin{tabular}{|c|c|c|c|c|c|}
\hline No & Category & Disclosure item & $\begin{array}{l}\text { Percentage of } \\
\text { companies that } \\
\text { disclose }\end{array}$ & $\begin{array}{l}\text { Percentage of } \\
\text { companies that do } \\
\text { not disclose }\end{array}$ & Total \\
\hline 5 & $\begin{array}{l}\text { Assurance of the } \\
\text { report to enhance } \\
\text { its credibility }\end{array}$ & $\begin{array}{l}\text { Assurance statement from an independent party, a reputable } \\
\text { accountancy firm or a technical expert }\end{array}$ & $50 \%$ & $50 \%$ & $100 \%$ \\
\hline
\end{tabular}


Table 3 (cont.). Disclosure of an assurance statement in the environmental report

\begin{tabular}{|c|c|c|c|c|c|}
\hline No & Category & Disclosure item & $\begin{array}{l}\text { Percentage of } \\
\text { companies that } \\
\text { disclose }\end{array}$ & $\begin{array}{l}\text { Percentage of } \\
\text { companies that do } \\
\text { not disclose }\end{array}$ & Total \\
\hline 5.1 & & $\begin{array}{l}\text { Assurance statement indicates adherence to internationally } \\
\text { recognized assurance standards such as the ISAE } 3000 \text { and the } \\
\text { AA1000 }\end{array}$ & $50 \%$ & $50 \%$ & $100 \%$ \\
\hline 5.2 & & Assurance statement indicates the type/level of assurance provided & $50 \%$ & $50 \%$ & $100 \%$ \\
\hline 5.3 & & $\begin{array}{l}\text { Assurance statement describes the assurance engagement and } \\
\text { identifies the subject matter }\end{array}$ & $50 \%$ & $50 \%$ & $100 \%$ \\
\hline 5.4 & & $\begin{array}{l}\text { Assurance statement identifies the responsible parties and describes } \\
\text { the assuror's responsibilities }\end{array}$ & $47 \%$ & $53 \%$ & $100 \%$ \\
\hline 5.5 & & $\begin{array}{l}\text { Assurance statement contains a summary of procedures performed } \\
\text { by the assuror }\end{array}$ & $49 \%$ & $51 \%$ & $100 \%$ \\
\hline 5.6 & & $\begin{array}{l}\text { Procedures performed include an assessment of risks of material } \\
\text { mistatements and testing accuracy of data reported }\end{array}$ & $47 \%$ & $53 \%$ & $100 \%$ \\
\hline 5.7 & & $\begin{array}{l}\text { Procedures performed include an assessment of reasonableness of } \\
\text { assumptions, significant estimates and judgements made in the } \\
\text { reporting process }\end{array}$ & $33 \%$ & $67 \%$ & $100 \%$ \\
\hline 5.8 & & $\begin{array}{l}\text { Procedures performed include a review of completeness of the } \\
\text { report, processes of determining material issues for reporting }\end{array}$ & $39 \%$ & $61 \%$ & $100 \%$ \\
\hline 5.9 & & $\begin{array}{l}\text { Procedures performed include a review of the accuracy of self- } \\
\text { declaration of the GRI, G3 application level }\end{array}$ & $35 \%$ & $65 \%$ & $100 \%$ \\
\hline 5.10 & & $\begin{array}{l}\text { Procedures performed include performing analytical procedures, } \\
\text { tests, comparison of information to underlying source documents }\end{array}$ & $39 \%$ & $61 \%$ & $100 \%$ \\
\hline 5.11 & & $\begin{array}{l}\text { Procedures performed include obtaining external confirmation and } \\
\text { management representation }\end{array}$ & $46 \%$ & $54 \%$ & $100 \%$ \\
\hline 5.12 & & Procedures performed by the assuror include interviews, site visits & $42 \%$ & $58 \%$ & $100 \%$ \\
\hline 5.13 & & $\begin{array}{l}\text { Procedures performed by the assuror include a review of the } \\
\text { systems that generate, record, collate, aggregate, monitor, correct } \\
\text { and report environmental information }\end{array}$ & $47 \%$ & $53 \%$ & $100 \%$ \\
\hline 5.15 & & $\begin{array}{l}\text { Conclusion that indicates that the environmental report has material } \\
\text { misstatements }\end{array}$ & $0 \%$ & $100 \%$ & $100 \%$ \\
\hline 5.16 & & $\begin{array}{l}\text { Conclusion indicates inherent limitations of conducting assurance on } \\
\text { environmental information }\end{array}$ & $29 \%$ & $71 \%$ & $100 \%$ \\
\hline 5.17 & & $\begin{array}{l}\text { Conclusion does not contain any disclaimer, reservations or denial of } \\
\text { a conclusion }\end{array}$ & $47 \%$ & $53 \%$ & $100 \%$ \\
\hline 6.5 & & $\begin{array}{l}\text { Conclusion contains a declaration that their environmental report met } \\
\text { the requirements of the GRI, G3 application level }\end{array}$ & $36 \%$ & $64 \%$ & $100 \%$ \\
\hline
\end{tabular}

To demonstrate the independence of the assurance provider, $47 \%$ of the sampled companies identified the responsible parties to the assurance engagement and described the assuror's responsibilities, whereas $49 \%$ outlined a summary of procedures performed by the assuror.

A closer examination of the summary of procedures performed by the assurors reveals that the procedures varied widely, perhaps, due to the diversity of the assurance providers, as well as due to a lack of generally accepted assurance framework. Specifically, $47 \%$ of the sampled companies in the current study disclosed that the summary of procedures conducted during the assurance process included an assessment of risks of material misstatements and testing of the accuracy of data reported. Only $37 \%$ disclosed that the procedures included an assessment of reasonableness of assumptions, significant estimates and judgments made in the reporting process. Similarly, only 39\% disclosed that the procedures included a review of completeness of the report, or review of processes of determining material issues for inclusion in the environmental report.

Consistently, only $35 \%$ disclosed that the procedures included a review of the accuracy of self-declaration of the GRI, G3 application level. 39\% of the sampled companies disclosed that the procedures included performing analytical procedures, tests, comparison of information to underlying source documents, whereas 46\% divulged that the procedures performed included obtaining external confirmation and management representation. $42 \%$ disclosed that the procedures performed by the assuror included interviews and site visits, whereas $47 \%$ disclosed that the procedures performed by the assuror included a review of the systems that generate, record, collate, aggregate, monitor, correct and report environmental information. Only $36 \%$ of the sampled companies disclosed that the procedures performed by the assuror included a review of internal controls relevant for the preparation of the environmental reports and the information therein. 
With regard to the disclosure of the assurance statement's conclusion, $50 \%$ of the sampled companies disclosed on this item. Interestingly, none of these companies' assurance statement's conclusion indicated that the environmental report had material misstatements. However, in contrast to the findings of similar prior studies (BSMC, 2010, p. 28; ACCA, 2009 , p. 19), $29 \%$ of the companies had assurance statement conclusions that disclosed weaknesses in systems, approaches and internal controls. Similarly, $29 \%$ of the sampled companies disclosed the inherent limitations of conducting assurance on environmental information. Of the sampled companies, $47 \%$ did not contain any disclaimer, reservations or denial of a conclusion in their assurance statements, while $36 \%$ of the companies had an assurance statement conclusion that contained a declaration that their environmental report met the requirements of the GRI, G3 application level claimed by the companies. Worse still the terms used to express an opinion varied widely in the assurance statements. With regard to the extension of the coverage of internal auditing to systems and procedures for measuring, recording, and reporting environmental information, only $30 \%$ of the sampled companies' indicated that they had done so.

\subsection{Disclosure of third party commentary, case} studies, success stories, international accreditation and the use of international guidelines. Apart from the use of independent assurance to enhance the reliability of an environmental report, a company can include third party commentary in its environmental report to enhance the report's credibility. Such commentary, preferably from influential stakeholder groups and reputable subject matter experts, can be used to reassure other stakeholder that the environmental report addresses all material issues, and that it is objective, complete and transparent. The commentary can, particularly, enhance reliability of the reports if it is in form of independent and unedited comment that includes resentful voices of stakeholders, with suggestions on how the quality of an environmental report can be improved. Equally effective is the use of case studies and success stories to demonstrate a company's connection to the reality faced by the stakeholders and its commitment to address the stakeholder's concerns. Therefore, the extent of disclosure of third party commentary, case studies and success stories can be used to gauge the reliability of environmental reports.

Obtaining an internationally recognized certification for an Environmental Management System (EMS), such as the ISO 14001, bolsters the credibility of a company's environmental reports as it indicates that its reporting process is systematic, based on sound policies, well-defined objectives and targets, and employs a sound EMS that complies with specified requirements.

The reliability of a company's environmental report can also be improved through the adoption of international reporting guidelines such as the GRI guidelines, which provides a comprehensive list of specific, standardized and reliable environmental performance indicators, against which the completeness of a company's report can be gauged. In addition, the GRI guidelines' performance indicators enable a company to quantify its performance, reduce errors and omissions, and ensure consistency in the recognition, measurement, and presentation of information in both the form and content over time, all which enhance the reliability of the reports. In short, the disclosure of third party commentary, case studies, success stories, international accreditation and the use of international guidelines can be used to gauge the reliability of a company's environmental report.

As shown in Table 4, 73\% of the sample companies disclosed third party commentary, case studies and success stories. Of the sampled companies, 99\% indicated that they had adopted the best practice in environmental performance management and reporting, however, only $53 \%$ of the companies indicated that they had adopted the best practice in environmental performance management, particularly with regard to international certification of their Environmental Management System (EMS).

From the results presented in Table 4, 92\% of the sample companies in the current study subscribed to or endorsed international guidelines such as GRI guidelines/principles or other initiatives. Table 4 further indicates that $91 \%$ of the sampled companies indicated that they comply with standards such as legal, industry, company or other standards. Likewise, $91 \%$ of the sampled companies mentioned that they comply with King III Report code of conduct.

Table 4. Disclosure of third party commentary, case studies, success stories, international accreditation and the use of international guidelines

\begin{tabular}{|c|l|l|c|c|c|}
\hline No & \multicolumn{1}{|c|}{ Category } & \multicolumn{1}{c|}{ Disclosure item } & $\begin{array}{c}\text { Percentage of } \\
\text { companies that } \\
\text { disclose }\end{array}$ & $\begin{array}{c}\text { Percentage of } \\
\text { companies that do } \\
\text { not disclose }\end{array}$ & \multicolumn{2}{c|}{$\begin{array}{c}\text { Total } \\
73 \%\end{array}$} & $27 \%$ \\
\hline 7 & $\begin{array}{l}\text { Third party } \\
\text { commentary }\end{array}$ & $\begin{array}{l}\text { Third party commentary on an environmental report's content, } \\
\text { including either direct quotes of influential stakeholder groups, } \\
\text { case studies, or success stories }\end{array}$ & $100 \%$ \\
\hline
\end{tabular}


Table 4 (cont.). Disclosure of third party commentary, case studies, success stories, international accreditation and the use of international guidelines

\begin{tabular}{|c|c|c|c|c|c|}
\hline No & Category & Disclosure item & $\begin{array}{l}\text { Percentage of } \\
\text { companies that } \\
\text { disclose }\end{array}$ & $\begin{array}{l}\text { Percentage of } \\
\text { companies that do } \\
\text { not disclose }\end{array}$ & Total \\
\hline \multirow[t]{5}{*}{8} & $\begin{array}{l}\text { International } \\
\text { accreditation and } \\
\text { use of international } \\
\text { guidelines/ } \\
\text { standards }\end{array}$ & $\begin{array}{l}\text { Indication whether the company has adopted the best } \\
\text { practice in environmental performance management and } \\
\text { reporting }\end{array}$ & $99 \%$ & $1 \%$ & $100 \%$ \\
\hline & & $\begin{array}{l}\text { Indication of adoption of best practice in environmental } \\
\text { performance management and reporting, including } \\
\text { international certification for the Environmental Management } \\
\text { System }\end{array}$ & $53 \%$ & $47 \%$ & $100 \%$ \\
\hline & & $\begin{array}{l}\text { Indication whether the company subscribes to or endorses } \\
\text { international guidelines such as GRI guidelines/principles or } \\
\text { other initiatives }\end{array}$ & $92 \%$ & $8 \%$ & $100 \%$ \\
\hline & & $\begin{array}{l}\text { Indication of whether the company complies with standards } \\
\text { such as: legal; industry; company or other standard }\end{array}$ & $91 \%$ & $9 \%$ & $100 \%$ \\
\hline & & $\begin{array}{l}\text { Indication of the company's compliance with King } 3 \text { code of } \\
\text { conduct }\end{array}$ & $91 \%$ & $9 \%$ & $100 \%$ \\
\hline
\end{tabular}

3.5. Disclosure of environmental information in a balanced manner, as well as risks and opportunities. For environmental information to be reliable, it must among other things, be neutral, impartial, objective or unbiased, so as not to unduly influence the user (FASB, 2010, p. 18). This requires equal disclosure of both positive and negative information including bad news, unresolved issues, areas that lack progress or improvement, missed targets, permanent problems, deficiencies, challenges, dilemmas, limitations, as well as contentious issues (Delloite Touche Tohmatsu, 2002). Similarly, only when a company can identify and quantify its environmental risks and opportunities can it reliably demonstrate its commitment to environmental issues, as this shows that environmental activities are genuinely integrated into a company's activities and are not a mere public relations campaign. Therefore, the extent to which a company discloses balanced information, identifies and quantifies its environmental risks and opportunities can partially be used to gauge the reliability of its environmental information. As summarized in Table 5, the environmental reports of $76 \%$ of the sample companies contained both positive and negative information to demonstrate balance in reporting. In addition, $74 \%$ of the companies disclosed their unresolved issues, areas in which they lacked progress or improvement, their missed targets, permanent problems, deficiencies, challenges, dilemmas, limitations and contentious issues.

Table 5. Disclosure of environmental information in a balanced manner, as well as risks and opportunities

\begin{tabular}{|c|c|c|c|c|c|}
\hline No & Category & Disclosure item & $\begin{array}{l}\text { Percentage of } \\
\text { companies that } \\
\text { disclose }\end{array}$ & $\begin{array}{c}\text { Percentage of } \\
\text { companies that do not } \\
\text { disclose }\end{array}$ & Total \\
\hline 9 & $\begin{array}{l}\text { Reporting in a } \\
\text { balanced manner }\end{array}$ & $\begin{array}{l}\text { Environmental report contains both positive and negative } \\
\text { information to demonstrate balance in reporting }\end{array}$ & $76 \%$ & $24 \%$ & $100 \%$ \\
\hline 9.1 & & $\begin{array}{l}\text { The environmental report includes unresolved issues, } \\
\text { areas that lack progress, lack improvement, missed } \\
\text { targets, permanent problems, have deficiencies, chal- } \\
\text { lenges, dilemmas, limitations, negative aspects/ conten- } \\
\text { tious issues }\end{array}$ & $74 \%$ & $26 \%$ & $100 \%$ \\
\hline 10 & $\begin{array}{l}\text { Risks and } \\
\text { opportunities }\end{array}$ & Mention of environmental risks and opportunities & $89 \%$ & $11 \%$ & $100 \%$ \\
\hline 10.1 & & $\begin{array}{l}\text { Description of how significant risks and opportunities are } \\
\text { identified and managed proactively including actions } \\
\text { undertaken to do so or plans to undertake such actions in } \\
\text { the future }\end{array}$ & $89 \%$ & $11 \%$ & $100 \%$ \\
\hline 10.2 & & Quantification of environmental risks or opportunities & $53 \%$ & $47 \%$ & $100 \%$ \\
\hline
\end{tabular}

With regard to the disclosure of risks and opportunities, $89 \%$ of the sampled companies mentioned their risks and opportunities. A similar percentage described how their significant risks and opportunities were iden- tified and managed proactively including actions undertaken to do so or plans to undertake such actions in the future. By contrast, only 53\% quantified their environmental risks and opportunities. 
3.6. Disclosure of environmental policies, objecttives and strategies. The adoption of a systematic environmental reporting process based on sound environmental policies, well-defined objectives and strategies does not only demonstrate the commitment of the company to continuous environmental performance improvement, but it also enhances the reliability of the company's environmental report. Therefore, the extent of disclosure of environmental policies, objectives and strategies can partially be used to gauge the reliability of an environmental report. As revealed in Table 6, 99\% of the sampled companies disclosed their environmental policy/mission, object- tives and strategies, whereas $68 \%$ of the companies set measurable standards, so that the environmental performance achieved could be compared to the objectives. $61 \%$ of the sampled companies disclosed that their environmental objectives have been met, whereas $99 \%$ described the action programs in place to execute the company's environmental strategy, and to show how actions are planned, organized and achievements are managed and controlled. 95\% of the sampled companies indicated that their environmental strategy was integrated to the core business strategy by integrating their environmental information with financial and social information.

Table 6. Disclosure of environmental policies, objectives and strategies

\begin{tabular}{|c|c|c|c|c|c|}
\hline No & Category & Disclosure item & $\begin{array}{l}\text { Percentage of } \\
\text { companies that } \\
\text { disclose }\end{array}$ & $\begin{array}{c}\text { Percentage of } \\
\text { companies that do not } \\
\text { disclose }\end{array}$ & Total \\
\hline 11 & $\begin{array}{l}\text { Policies, objectives } \\
\text { and strategies }\end{array}$ & Environmental policy/mission, objectives and strategies & $99 \%$ & $1 \%$ & $100 \%$ \\
\hline 11.1 & & $\begin{array}{l}\text { Set measurable standards so that the environmental } \\
\text { performance achieved may be compared to the objectives }\end{array}$ & $68 \%$ & $32 \%$ & $100 \%$ \\
\hline 11.2 & & Disclosure if the objectives have been met & $61 \%$ & $39 \%$ & $100 \%$ \\
\hline 11.3 & & $\begin{array}{l}\text { Description of action programs in place to execute the } \\
\text { company's environmental strategy, and to show how } \\
\text { actions are planned, organized, and achievements are } \\
\text { managed and controlled }\end{array}$ & $99 \%$ & $1 \%$ & $100 \%$ \\
\hline 11.4 & & $\begin{array}{l}\text { Indication whether the environmental strategy is integrated } \\
\text { to the core business strategy; evidenced by the integration } \\
\text { of environmental information with financial and social } \\
\text { information }\end{array}$ & $95 \%$ & $5 \%$ & $100 \%$ \\
\hline
\end{tabular}

In general, the disclosure of items that enhance the reliability of the sustainability reports discussed above by an overwhelming majority of companies is encouraging but there are many areas in which the low level of disclosure undermines the reliability of the environmental reports. These include use of top management statement for declaration of commitment to address key concerns raised by stakeholders and to invite stakeholders' feedback, as well as for disclosure of broader trends and progress on targets.

Another key area of disclosure, and, arguably, the most important one that should be improved is the disclosure of assurance of the environmental report. The fact that only $50 \%$ of companies' environmental reports had an assurance statement is a reason for concern, as it suggests that the remaining half presented unsubstantiated reports, which raises questions about their reliability. Even for the reports that have an assurance statement, the assurance type adopted by most is limited, and covers only certain selected issues, is not company wide and employs varying procedures. Equally discouraging is that only $30 \%$ of the companies disclosed that they had extended their internal auditing coverage to environmental issues. Other areas in which disclosure must be improved to enhance the reliability of the environmental reports is the certification of the EMS, as well as the quantification of environmental risks and opportunities.

\section{Summary and conclusions}

This paper sought, by way of a content analysis methodology, to assess the reliability of environmental reports produced by the T100LSA companies. The results of this paper indicate that almost all of the company's environmental report had a statement from the top management indicating environmental successes, failures and challenges, top management commitment to and involvement in addressing environmental challenges, commitment in implementing company environmental principles, values, policies, and strategies. In addition, most companies had a top management statement that referred to key elements of the report, thus set the tone for the rest of the report. However, only $50 \%$ of the companies' top management statements included broader trends in environmental performance, and progress on targets. Furthermore, only a minority of the companies' statements contained top management's commitment to address key concerns raised by stakeholders and invited them to provide feedback on the report. Nonetheless, almost all of the sampled companies described their organizational structures that deal with environmental matters, indicated that the oversight of environmental issues is done at the 
board level, mentioned the roles and responsibilities of officials in charge of environmental matters including those who bore the ultimate responsibility for environmental issues.

The results further revealed that most of the sampled companies described the initiatives undertaken to mitigate environmental impacts, the external recognition for environmental achievements, such as awards and favourable rankings, as well as their involvement with third parties in environmental initiatives.

As far as the assurance of the environmental reports is concerned, the results revealed that only $50 \%$ of the sampled companies' reports contained an Assurance statement. These statements adhered to internationally recognized assurance standards, disclosed the type/level of assurance provided, described the assurance engagement, as well as identified the subject matter. Only a minority of the companies' statements identified the responsible parties, described the assuror's responsibilities, or even contained a summary of procedures performed by the assuror. Interestingly, none of the sampled companies' statement's conclusion indicated that the environmental report has material misstatements, while only $3 \%$ contained any disclaimer, reservations or denial of a conclusion. Only a small percentage of the sampled companies' statement's conclusion indicated the inherent limitations of conducting assurance on environmental information.

The results further revealed that most of the sampled companies' environmental reports contained third party commentary on the report's content. In addition, almost all of the sampled companies disclosed that they had adopted best practice in environmental performance management and reporting including complying with GRI requirements. Furthermore, the results indicated that most of the sampled companies' environmental reports contained both positive and negative information to demonstrate balance in reporting, and that most discussed the environmental risks and opportunities faced, although they did not always quantify them. Besides, most of the sampled companies had an environmental policies, missions, measurable objectives and strategies in place. Most also went ahead and reported whether the objectives had been met, including the action programs for doing so. Similarly, most indicated that their environmental strategy had been integrated into their core business strategy.

Taken together, the above results indicate that the environmental reports produced by listed South Africa, companies are reliable. However, the results suggest some areas in which the reliability of the reports could be improved, key among which include the inclusion in the top management statement, a declaration of their commitment to address key concerns raised by stakeholders, and an invitation tothe latter to provide feedback on the report. Another notable area that needs improvement relates to the assurance of the environmental reports which significantly lags that of financial reports, particularly with regard to the summary of procedures performed by the assuror.

The findings of this article have implications for listed South African companies, as they will be made aware of various approaches adopted by their counterparts to enhance the reliability of their environmental reports in order to address the lingering trust deficit between the general public and the intentions and practices of the companies. This information should not only enhance their buyin on the need to produce reliable environmental reports, but also should enable them to evaluate their own environmental reporting practice in order to decide whether to improve, change or continue with their current practice. Researchers may also employ the content analysis approach, such as the one adopted in this study, to evaluate the other qualitative characteristics that make a non-financial report more decision-useful such as relevance, comparability, understandability.

\section{References}

1. ACCA. (2009). Key issues in sustainability assurance. Available at: http://www2.accaglobal.com/pubs/general/ activities/research. [Accessed: 19 November 2010].

2. AICPA, CICA \& CIMA. (2010). Evolution of corporate sustainability practices perspectives from the UK, US and Canada. Available at: http://www.cica.ca/research-and-guidance/mda-and.../item45663.pdf. [Accessed: 16 February 2011].

3. Alrazi, B., De Villiers, C. \& Van Staden, C. (2011). The comprehensiveness of environmental reporting by global electric utilities: The type of information and the reporting media. Paper submitted at the NZ Sustainability Accounting Research Symposium, Auckland. August.

4. Bond, D. (2013). Governing disaster: the political life of the environment during the BP oil spill, Cultural anthropology, 28(4), pp. 694-715.

5. BSMC. (2010). Survey of best practices, trends and benchmarks in sustainability reporting. Available at: http://www.businessandsociety.be/.../883c0525 [Accessed: 28 December 2010].

6. Cohen, E. (2014). The TOP TEN Sustainability Reports of 2014. Available at: http://csr- 
reporting.blogspot.co.za/2014/12/the-top-ten-sustainability-reports-of.html. [Accessed: 28 February 2016].

7. Delloite Touche Tohmatsu (DTT). (2002). Deloitte Sustainability Reporting Scorecard. Available at: http://www.deloitte. com/ assets/ Dcom.../DTT_ERS_FullScorecard_032106.pdf. [Accessed: 15 January 2011]

8. Delmas, M. \& Burbano, V.C. (2011). The Drivers of Greenwashing, California Management Review, 54(1), pp. 64-87.

9. De Villiers, C. \& Van Staden, C.J. (2010). Shareholders' requirements for corporate environmental disclosures: a cross country comparison, British Accounting Review, 429(4), pp. 227-240.

10. Ernst \& Young. (2007). Keep the balance Steady: survey on the quality of sustainability reports 2007. Available at: http://www.ec.europa.eu/enterprise/newsroom/cf. [Accessed: 23 January 2011].

11. Emtairah, T. (2002). Corporate environmental policy: review of policy action in Europe. Available at: http://www.iiiee.lu.se/commerce/research. [Accessed: 5 August 2009].

12. FASB. (2010). Conceptual framework: statement of financial accounting concepts No. 8. Available at: http://www.www.fasb.org/cs/BlobServer?blobcol...id....application\%2Fpdf. [Accessed: 15 January 2011].

13. Fonseca, A. (2010). Barriers to strengthening the Global Reporting Initiative framework: exploring the perceptions of consultants, practitioners, and researchers. http://www.csinrcid.ca/downloads/csin_conf_alberto_fonseca.pdf. [Accessed: 13 June 2011].

14. Furmann, S., Ott, C., Looks, E. \& Gunther, T.W. (2013). The Contents of Assurance Statements of Sustainability Reports and Information Asymmetry. Available at: http://arw-suisse.ch/wp-content/uploads/2013/05/fuhrmannetal1.pdf.[Accessed: 16 September 2014].

15. Ernst, Young \& Greenbiz. (2013). Six growing trends in corporate sustainability. Available at: http://www.ey.com/Publication/vwLUAssets.pdf. [Accessed: 16 September 2014] [Accessed: 28 May 2011].

16. Global Reporting Initiative (GRI). (2000). Sustainability reporting guidelines on economic, environmental and social performance. Available at: http://www.globalreporting.org/NRR/../SR_FINAL_09_06_with_links.pdf. [Accessed: 24 March 2010].

17. Haque, S., Deegan, C. \& Inglis, R. (2013). Disclosure of climate change-related corporate governance practices. Paper presented at the Asia Pacific Interdisciplinary Research in Accounting Conference, Kobe, Japan. July.

18. Hibbit, C. (2004). External environmental disclosure and reporting by large European companies: An economic, social and political analysis of managerial behavior. Available at: http://www.rozenbergps.com/files/hibbit.pdf. [Accessed: 23 December 2010].

19. IRC. (2011). Framework for integrated reporting and the integrated report discussion paper. Available at: http://www.sustainabilitysa.org [Accessed: 22 August 2011].

20. Jollands, S., Akroyd. C. \& Sawabe, N. (2012). Investigating the role of stand-alone sustainability reports. Available at: http://www.apira2013.org/proceedings/pdfs/K300.pdf. [Accessed: 23 October 2012].

21. Kolk, A. (2005). Sustainability reporting, VBA Journal, 21(3), pp. 34-42.

22. KPMG. (2013). The KPMG Survey of Corporate responsibility reporting 2013. Available at: http://www.kpmg.com/global/en/issuesandinsights. [Accessed: 31 December 2013].

23. Leavoy, P. (2010). Does CSR Reporting Help the Planet, or Just Help Reporting? Available at: http://www.greenbiz.com/blog/2010/09/30/does-csr-reporting. [Accessed: 12 January 2011].

24. Marquis, C. \& Toffel, M.W. (2014). Scrutiny, Norms, and Selective Disclosure: A Global Study of Greenwashing. Available at: http://www.hbs.edu/faculty/ [Accessed: 18 February 2016].

25. Mitchell, C.G. \& Quinn, N.W. (2005). Environmental reporting disclosure in South Africa: A comparative study of the expectations of selected groups of preparers and users, Meditari Accounting Research, 13(2), pp. 17-33.

26. Said, R.M., Sulaiman, M., Ahmad, N.N. \& Senik, R. (2013). Environmental information usefulness: bank officers perceptions in Malaysia. Paper presented at the 4th international conference on business and economic research, Bandung, Indonesia. March.

27. Strandberg Consulting. (2013). Sustainability reporting trends and implications. Available at: http://corostrandberg.com/wp-content/uploads/2013/12/.pdf. [Accessed: 16 September 2014].

28. Sustainability, FBDS, UNEP. (2008). The Road to Credibility a survey of sustainability reporting in Brazil. Available at: http://www.unep.fr/scp/gripdf. [Accessed: 24 March 2011].

29. Zadjali, N. (2011). Advantages and disadvantages of Content Analysis. Available at: https://nuhaalzadjali 9oo00oo9.wordpress.com/2011/01/10. [Accessed: 30 June 2015]. 